\title{
POTENTIAL OF ECOTOURISM: COMPARATIVE ANALYSIS OF SLOVAKIA AND SERBIA
}

\author{
Lucia Škvareninová ${ }^{1}$ \\ Mario Lukinović ${ }^{2}$ \\ Larisa Jovanović ${ }^{3}$
}

DOI: https://doi.org/10.31410/LIMEN.S.P.2020.121

\begin{abstract}
The demand for nature and ecotourism has been constantly rising last forty years and it will continue to grow. Due to the coronavirus, domestic tourism will increase exponentially, which would enhance ecotourism development. Foreigners and local tourists have become more aware to leave a positive impact on the environment where they travel and where they live. Serbia and Slovakia have a great potential to become attractive ecotourism destinations. Both countries are countries with a similar population number, no access to the sea, but with preserved nature, great gastronomic offer, and the main potential next to the capitals of Bratislava and Belgrade lies in ecotourism. At the same time, domestic ecotourism is a perfect economic activity that promotes sustainability and development. In the less developed regions, ecotourism can bring new employment opportunities and increase demand for local products. Agrotourism and rural tourism are inevitable part of sustainable development in Slovakia and Serbia. Despite of small territories of Slovakia and Serbia, both countries can offer a wide range of sceneries and natural beauties to be explored.

This article aims to analyze the potential of ecotourism in the Slovak Republic and Serbia. To achieve the objective results, we've surveyed the foreign and local respondents. Our study also analyzes whether marketing strategies and promotion of domestic ecotourism is effective to attract tourists. The obtained results will be evaluated and compared. In the last part, the paper focuses on eco labels that currently exist in Serbia and Slovakia.
\end{abstract}

Keywords: Ecotourism, Agrotourism, Natural resources, Local products, Protected areas, Marketing, Eco label.

\section{INTRODUCTION}

$\mathrm{T}$ The number of tourists in the world has grown over the past seventy years from 50 million people in 1950 to a staggering 1.4 billion in 2019 (UNWTO World Tourism Barometer). This figure would not be disturbing in itself if it were not accompanied by a number of negative factors that endanger the environment. For example, in luxury hotels, 1,800 liters of water are consumed per guest per day (for bathing, washing bed linen and towels, etc.), while a village of 700 inhabitants in one of the developing countries consumes 500 liters of water per month (www.travelmagazine).

Awareness of ecotourism does not date back to the distant past. Ecotourism is often referred to as sustainable tourism because of its tendency towards minimal impact on the environment and local culture (Janković et al., 2020). Ecotourism is important because of the reduction of

\footnotetext{
Department of Landscape Management, Faculty of Forestry and Wood Technology, Brno, Czech Republic Faculty of Law, Union University, Belgrade, Serbia

ALFA BK University, Belgrade, Serbia
} 
negative impacts and contributions to environmental protection, but also as a generator of income, especially in rural areas.

It is important to point out that ecotourism is a form of tourism that focuses on areas of preserved environment, and possible ecotourism destinations can include national parks, protected natural areas, rural areas, areas of rich biodiversity with low levels of construction and urbanization (Milićević et al, 2019).

Recreation and ecotourism services have brought great opportunities to the people living in rural areas: new jobs, improved quality, of education, protection of unique culture and local customs. Recreational activities maximized the potential of historical and cultural sites that attract tourists from all around the globe. (Škvareninová, Kupec, 2019).

Ecotourists are motivated by the awareness of the endangerment of the environment. Awareness of climate change is changing the perception of average tourists and moving it towards ecotourism. According to Booking.com 2019 Sustainable Travel Report, 70\% of the world's tourists would book environmentally friendly accommodation when choosing a tourist destination. According to the same report, almost three quarters (72\%) of travelers are not aware of the existence of eco-labels for accommodation, although $62 \%$ of them would feel better about staying in accommodation with an eco-label. Also, eco-tourists travel more often than other tourists, and according to one of the surveys, 38\% of them are interested in archeological sites / caves, $22 \%$ - in wild animals and birds (living in their natural habitat), $18 \%$ - in national parks visits, and $16 \%$ - in the culture of local communities (Travel Guard Update, April 2013).

\section{POTENTIAL OF ECOTOURISM IN SLOVAKIA}

The Slovak Republic is a landlocked country located in Central Europe with rich biodiversity. Despite its small territory, it offers many recreational activities such as hiking, swimming, skiing, discovering cultural monuments and local nature, unique for its flora and animal species. The oldest protected area, the National Park of Tatras (TANAP), is home to a number of endemic wildlife: kamzík vrchovský tatranský (Rupicapra rupicapra tatrica), svišt' vrchovský tatranský (Marmota marmota latirostris), hraboš snežný tatranský (Microtus nivalis mirhanreini) (Štátne lesy TANAPu). Environmental awareness among local tourists leads to greater demand for more sustainable practices; therefore, traditional tourism is becoming challenged. More protective environmental measures in tourism industry are expected not only by public, but these goals are also incorporated in the document Zelenšie Slovensko -Greener Slovakia.

Integration of the territory of Slovakia into European and international programs for nature protection, is supportive precondition to belong to the system of protected European areas NATURA 2000, The European Diploma for Protected Areas and the UNESCO World Cultural and Natural Heritage. (Wiezik, M. et al., 2019). In Slovakia, there are 9 national parks, 14 protected landscape areas and a network of so called "small- scaled protected areas" (protected sites, nature reserves and nature monuments). An overlap of proposed NATURA 2000 network with currently existing protected areas is $68 \%$ (Baláž, D. et al, 2005).

Since many years ago, dating in the time of Austro-Hungarian Empire, the foreign tourists have been attracted to visit this land for its famous natural mineral and thermal springs. Many of them are recommended by doctors and medical specialists for its physical healing effects. In 
order to treat digestive problems, heart diseases, skin and other individual body parts problems, courses of balneotherapy and hydrotherapy are prescribed in the SPA Trenčianske Teplice, Kováčová, Piešt’any, Bojnice, etc. as a part of a treatment program. More than 1300 mineral sources and over 7100 of caves are found within the territory of Slovakia. Moreover, Slovakia has the highest number of caves per person in Europe.

Opportunities for ecotourism are limitless. Many ecotourism spots in Slovakia are still unknown for foreigners, but also among local tourists. Few of them are introduced here: Šranecké piesky known as "Slovak Sahara" with its unique flora and fauna. This area is protected by the EU. The other unusual ecological area is in Čadca city, where special stone balls called "Megoňky" can be found. It is the largest natural stone balls location in Europe. The turquoise water surrounded by beautiful nature known as "Slovak Plitvice lakes" is situated in Malá Fatra.

The Slovak Republic possesses great resources of geothermal energy, which is important and very perspective source of renewable energy. Both countries, Slovakia and Serbia, don't fully use geothermal energy capacity and its potential as an alternative source of energy.

\section{RESEARCH METHODS}

In order to obtain scientific results, we've conducted quantitative research method comprised of questionnaire with the intention of efficient gathering of data from two groups of respondents: Group 1- foreign respondents and Group 2- local inhabitants of the Slovak Republic. Our survey consists of closed ended questions. The data were collected from 20 foreign respondents and 50 Slovak respondents. The aim of this survey is to analyze the current development and the potential of ecotourism in Slovakia from the point of view of local people and foreigners. We would like to find out whether marketing strategies to promote ecotourism are efficient, and also to define the preferences of local buyers and quality of local agricultural products. Conclusion will be drawn from obtained results.

\section{RESULTS}

\section{Group 1}

Question 1. Do you consider Slovakia as an environmentally friendly country?

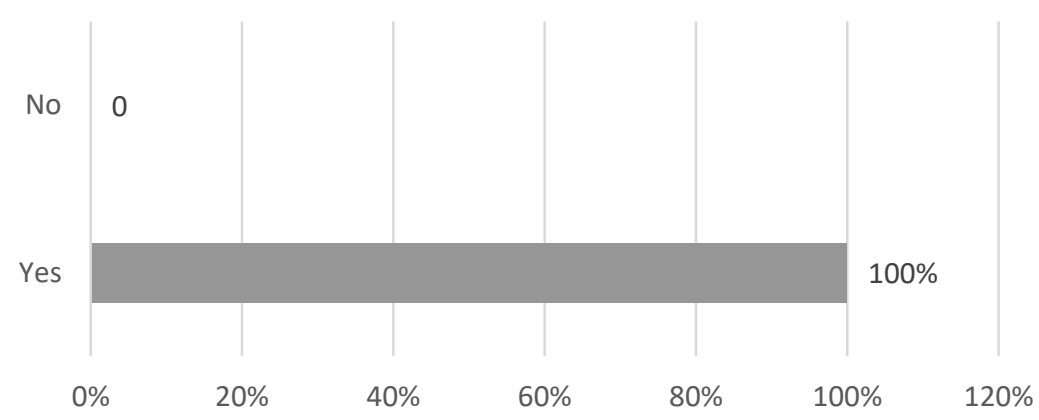

Source: own elaboration, Škvareninová, 2021

All respondents agreed, that Slovak Republic can be considered as an environmentally friendly country. All foreigners have already got in contact with the Slovak Republic before conducting a survey; 12 out of 20 foreign respondents have already visited Slovakia, 8 people have depended on secondary information and own knowledge. 
Question 2. How is the marketing of the Slovak republic?

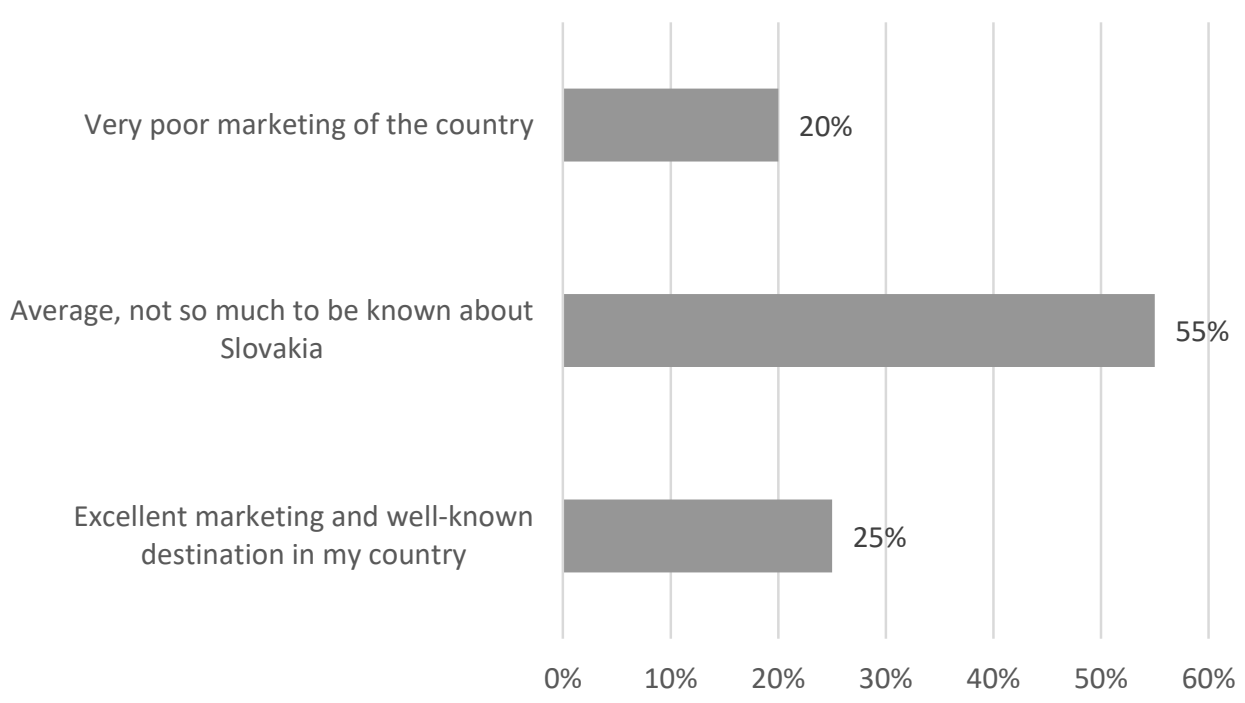

Source: own elaboration, Škvareninová, 2021

$55 \%$ of foreign respondents believe that marketing of the Slovak Republic is average and it is not much to be known about this country. $25 \%$ of respondents proclaimed that Slovakia has an excellent marketing and it is well-known destination in their home country. The answer "very poor marketing of the country" has been chosen by $20 \%$.

Question 3. Please select area, which can be associated with Slovakia

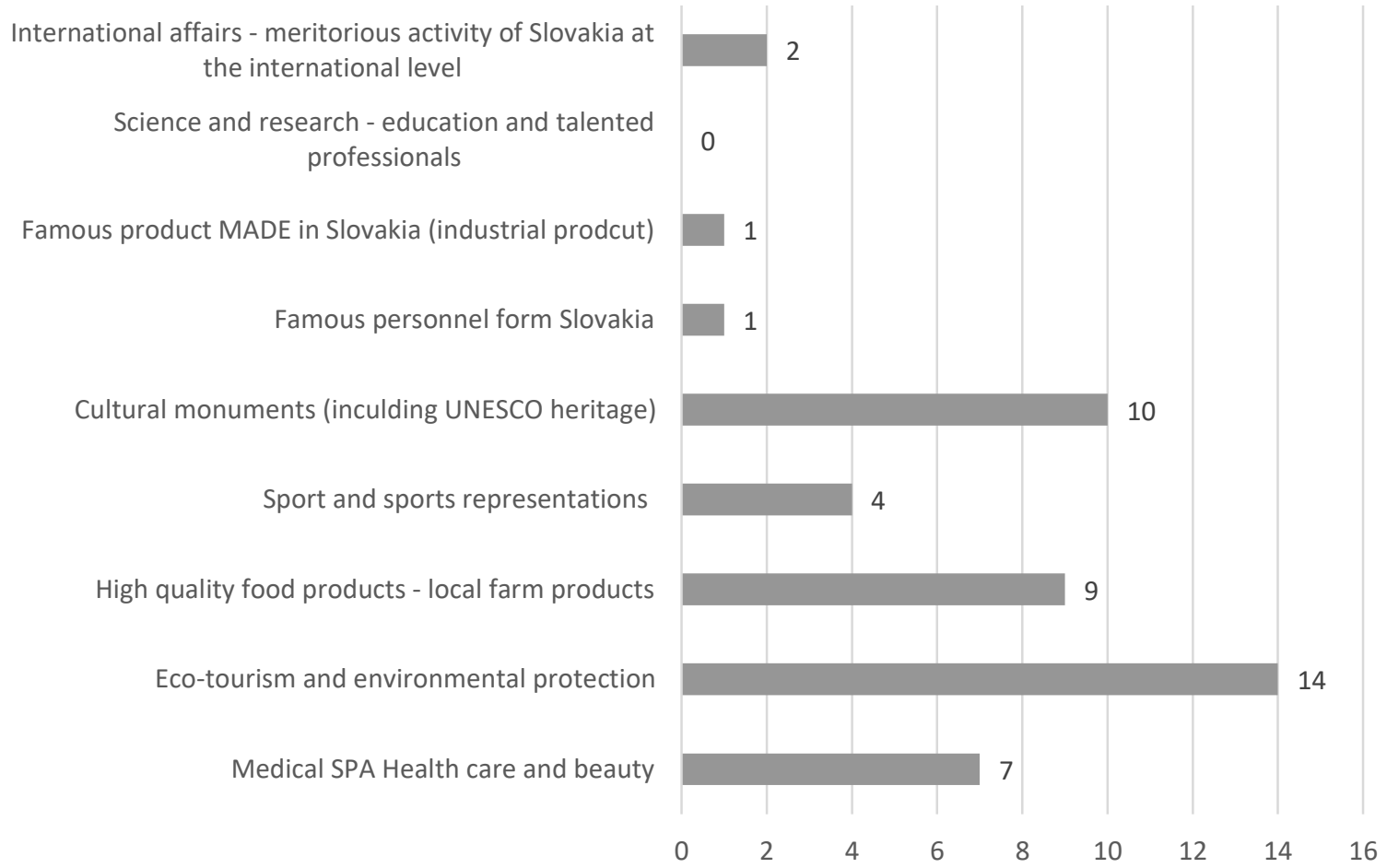

Note: In question 3, the respondents can choose min. 1 and max. 3 answers.

Source: own elaboration, Škvareninová, 2021 
The answer "Ecotourism and environmental protection" obtained the highest number, which was selected by 14 respondents. The second most frequent answer "Cultural monuments (including UNESCO heritage)“" was chosen by 10 people. The third most preferred area, which can be associated with Slovakia, according to the foreigners is "High quality food productslocal farm products". Other 6 areas which can be associated with this country are comparably less relevant from the foreigners' point of view.

Question 4. In your opinion, is Slovakia an attractive tourist destination?

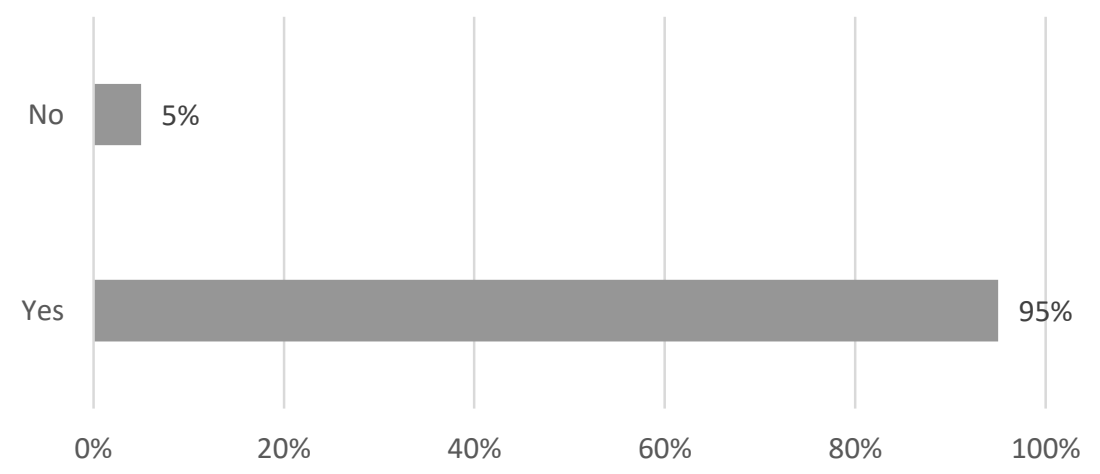

Source: own elaboration, Škvareninová, 2021

The vast majority, $95 \%$ of all respondents are convinced that Slovakia is an attractive touristic destination. Only 5\% (1 respondent) thinks that Slovakia is not an attractive touristic destination.

Foreign respondents judge Slovakia either according to their own first-hand experience or the secondary source of information and knowledge they've gained about the Slovak Republic. Slovakia isn't an unknown destination to them. Surprisingly, all foreigners agreed that Slovakia can be considered as environmentally friendly country. Such positive perception about Slovakia brings many opportunities and new challenges in the field of environmental protection. On the other hand, marketing of the Slovak Republic is not viewed by foreigners in the most positive light. There are obviously many ways, how to improve the marketing of the country abroad. It means, that not only general Slovak population, but especially the representatives of the state bear the responsibility to introduce their homeland as an attractive touristic destination. Inevitable role of the government and the state representatives is to create a positive image of the country who they represent, in order to attract the foreigners and to widen the general knowledge about Slovakia among other foreigners abroad. The results of the survey show, that more attention should be paid to the marketing and the country promotion; foreigners are interested to know more about Slovakia, but very limited information is accessible. In order to achieve more positive results in the future, the Slovak Republic should work effectively on the marketing strategies promoting the country. Based on proposed results, it can be concluded that Slovakia doesn't fully use its own touristic potential and attractive ecotourism spots are lacking promotion abroad.

In Question 3, the respondents have chosen three areas, which can be associated with Slovakia the most. Surprisingly, the answer Ecotourism and environmental protection was chosen by majority of respondents. Cultural monuments and high-quality food products (local farm products) belong to the three top categories. 


\section{Group 2}

Question 1. In your opinion, does Slovakia have potential in ecotourism?

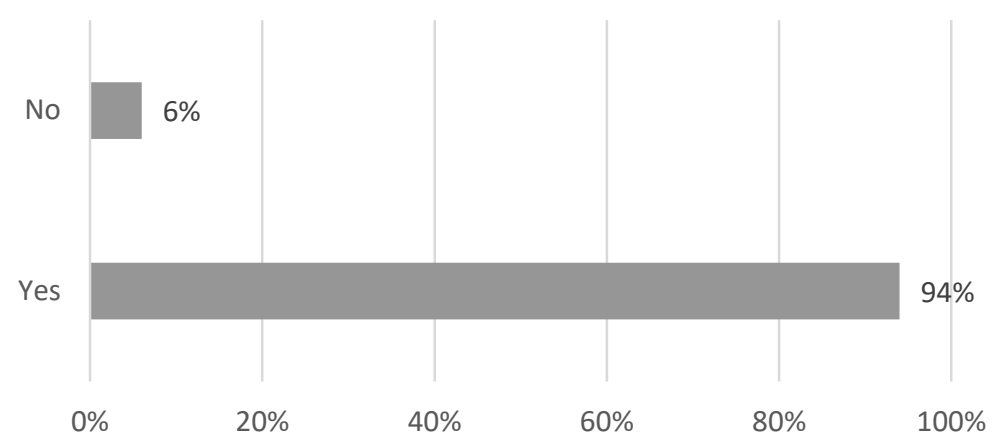

Source: own elaboration, Škvareninová, 2021

Vast majority of respondents, $94 \%$ believe that Slovakia has a potential in ecotourism. Only $6 \%$ of respondents do not agree with this argument.

Question 2. In your opinion, are the marketing strategies effective enough to promote local ecotourism in various Slovak regions?

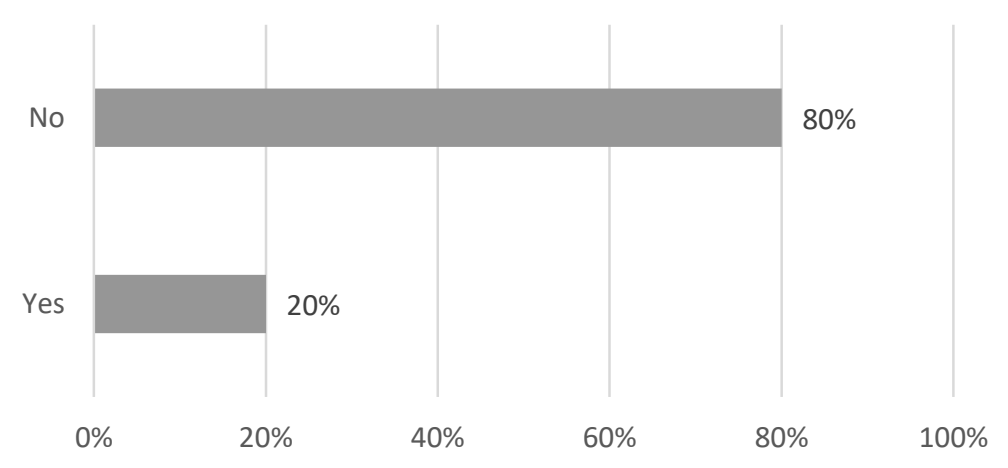

Source: own elaboration, Škvareninová, 2021

According to $80 \%$ of local respondents, marketing strategies are not effective enough to promote the local ecotourism in various Slovak regions. Only 20\% people believe that existing marketing strategies are effective to promote ecotourism in different regions.

Question 3. Do you have personal experience with ecotourism in your country?

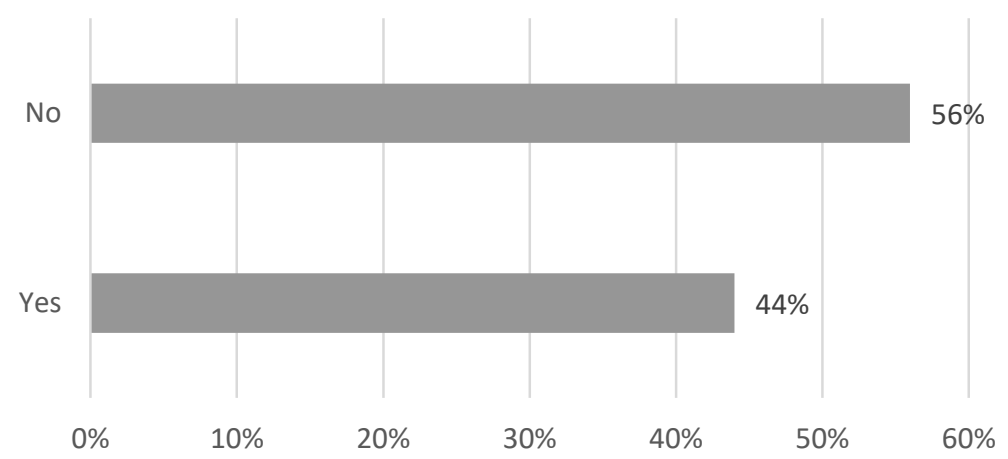

Source: own elaboration, Škvareninová, 2021 
More than a half, 56\% of respondents claimed that they have personal experience with ecotourism in Slovakia. 44\% of Slovak respondents haven't any experience with ecotourism in their own country.

Question 4. In terms of quality, are the local products competitive enough compared to imported products?

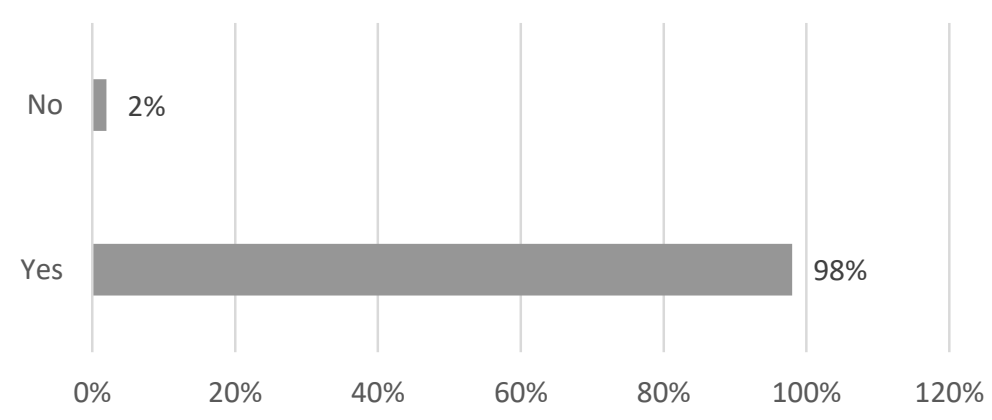

Source: own elaboration, Škvareninová, 2021

Almost all respondents are convinced about high quality of local Slovak products and claimed that local products are competitive enough compared to imported products. Only $2 \%$ don't believe so.

Question 5. Do you prefer to buy local agricultural products rather than imported products?

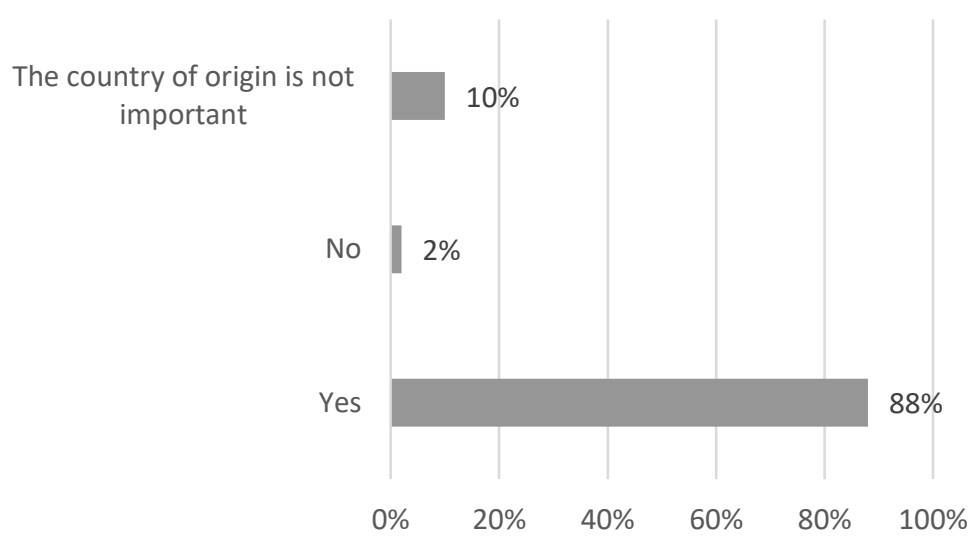

Source: own elaboration, Škvareninová, 2021

$88 \%$ of respondents prefer to buy local agricultural products rather than imported. $10 \%$ don't consider the country of origin as an important factor. Only $2 \%$ of local respondents don't prefer to buy local agricultural products, but they rather prefer to buy imported products.

The results of survey among local respondents in Slovakia has shown that the Slovak Republic has a great potential in ecotourism; however, the marketing strategies to promote ecotourism in various regions in Slovakia is definitely not effective. Possibly, due to the lack of ecotourism promotion, many Slovak people haven't experienced ecotourism in their own country yet. With regards to the quality of local products, almost all local respondents believe that Slovak products are competitive compared to imported products. Majority of local people prefer to buy local agricultural products rather than imported products. 


\section{POTENTIAL OF ECOTOURISM IN SERBIA}

The tourist potential of Serbia is conditioned by many different factors. The Republic of Serbia is a country in Southeast Europe. It has significant archeological sites, some of which were created in the period of 40,000 years before the new era, the most important of which are Lepenski vir and Vinca Belo brdo. However, undoubtedly the largest number of historical sites originate from the time of Ancient Rome - as many as 17 Roman imperators ones were born on the territory of today's Serbia, including Marcus Aurelius Probus, the first Roman emperor who allowed the planting of vines outside Italy.

Serbia has exceptional preconditions for the development of eco-tourism in terms of natural resources, cultural heritage, traditional indigenous food and accommodation in ethno villages, farmhouses and small hotels on the edge of protected areas. Tourists who choose to go on a vacation in the countryside, mountain or near protected areas want to at least briefly leave life in the urban environment, while learning about the traditions and peculiarities of these areas (Jovanović et al, 2019).

In the Republic of Serbia, the number of protected areas is constantly growing. Based on the applied measures of institutional nature protection for more than six decades, the area of protected areas in Serbia covers about $8 \%$ of the territory of Serbia and currently amounts to 662,435 ha. There are 461 protected areas under protection, which are protected under the Environmental Protection Act (EPA, 2004) and the Cultural Property Act (CPA, 1994):

- 5 national parks,

- 18 nature parks,

- 20 landscapes of exceptional quality,

- 68 nature reserves,

- 3 protected habitats,

- 310 nature monuments,

- 38 cultural and historical sites.

All these areas can be used as eco-destinations with significant potential for the development of eco-tourism and various forms of entrepreneurship. Wetlands are protected internationally by the Ramsar Convention (RC, 1971). Ramsar wetlands represent resources of great importance for biodiversity conservation. They provide habitats for migratory bird species, which, because of their seasonal movements and cross-country movements, are considered international resources (Štetić, Trišić, 2020). The local population of Ramsar areas and surrounding villages has direct and indirect profits from the growth of this type of ecotourism (Zasavica, Obedska swamp, Imperial swamp, Ludash Lake).

In recent years, the restoration of medieval fortresses throughout Serbia (Golubac, Ram, Bač) has begun, which has attracted a lot of attention, especially from domestic tourists. However, as Serbia does not have the sea and a significant number of ski centers, the largest number of domestic and foreign tourists are focused on spa and rural tourism (Mladenović, Bojičić, 2020). Although spa tourism in Serbia is regenerating, it is noticeable that it is insufficiently used, primarily in the segment of thermo-mineral, mineral and thermal waters (Milićević et al, 2019).

Eco tourism in previous years was not a branch of tourism that could generate a significant number of tourist visits, but with all the changes brought by globalization and modern trends 
in modern life, an increasing number of tourists are interested in vacationing in nature, far from urban centers.

Preserved natural resources are one of the competitive advantages of tourism development. Serbia has an unusually large diversity of natural animal habitats: from wetlands to arid steppes and mountain gorges. Many plant and animal species can be observed in Serbia, which is their only remaining habitat. The aquatic insect Tisza mayfly (Palingenia longicauda), can be found today only in the bed of the river Tisza and some of its tributaries. Aldrovanda vesiculosa - a rootless plant that lives freely floating on the water of ponds, which is critically endangered in Europe, can be observed in the Special Nature Reserve Zasavica (Sačuvajmo čudesne vrste, IUCN Red List). This plant captures small aquatic invertebrates using traps similar to those of the Venus flytrap.

Serbia is one of the six centers of biodiversity in Europe. Although it covers about $2 \%$ of Europe's total territory, it is home to 44,200 taxons (species and subspecies) and one of the largest hotspots of biodiversity in which $67 \%$ of Europe's mammal fauna is represented. Its territory is home to $51 \%$ of Europe's fish fauna, $49 \%$ of Europe's reptile and amphibian fauna and 39\% of Europe's vascular flora (Biodiverzitet Srbije, IUCN, Red List). The fact that 67\% of butterfly species live on the territory of Serbia is especially important because day and night butterflies are the most important bioindicators among terrestrial insect's habitats and an indicator of the degree of environmental protection, due to their exceptional sensitivity to negative changes in habitats.

Bird watching has developed in recent years into one of the most popular and fastest growing nature-based tourism activities (Carver, 2013). This group of tourists is also ready for higher travel expenses (Krejić et al, 2019). More than 70\% of the bird fauna of Europe lives in Serbia, hereof it is one of the most desirable locations for bird watching, to which migratory species additionally contribute.

By analyzing the natural resources of Serbia, it is concluded that their diversity, exceptional quality and attractiveness represent distinguished potential for the development of Serbian ecotourism.

\section{ECOLOGICAL LABELS - AN OPPORTUNITY TO INCREASE THE CURRENT TOURIST POTENTIAL OF SERBIA AND SLOVAKIA}

Given that it is not possible to label services and products in Serbia with EU eco-labels, until the moment when Serbia becomes an EU member or enters the European Economic Zone, and aware of an increasingly wider circle of environmentally conscious consumers, the Government of the Republic of Serbia in 2009. adopted the Rulebook on detailed conditions, criteria and procedure for obtaining the right to use the eco-label, elements, appearance and manner of using the eco-label for products, processes and services (Official Gazette of the Republic of Serbia, No. 3/2009). The Rulebook was amended in 2016 (Official Gazette of RS, No. 49/2016), when the criteria for 26 different groups of products and services were prescribed in accordance with the relevant criteria in the European Union.

The Ecological label of the Republic of Serbia is a mark that can be used to mark products and services that are produced on the territory of Serbia and which are determined to meet the criteria set by the Ordinance, and relate to less negative environmental impact than existing ones on the market. The Ecolabel criteria for tourist accommodation services aim in particular to: limit energy consumption, limit water consumption, limit waste generation, promote the use 
of renewable sources and substances that are less dangerous to the environment and promote communication and education related to environmental protection middle. At least $50 \%$ of the electricity used for all purposes in tourist accommodation must come from renewable sources, except in cases where tourist accommodation does not have access to a market that offers electricity from renewable energy sources (Čavlin et al., 2018). Strict conditions are also prescribed regarding the efficiency and production of heat, the way of air conditioning of the facility, energy efficiency of accommodation and service facilities, insulation of windows, ways in which heating, air conditioning and light are turned off and on. The part related to water consumption (flow of water from taps and showers, flushing of toilets, change of towels and bed linen, discharge of wastewater) and regulation and waste management (waste separation, disposable products, breakfast packaging) are especially regulated in detail.

The Slovak Republic did not establish own, nationally recognized Ecological label, because it is part of the European Union and doesn't have national unified standard due to the fact that the certification of ecological tourist accommodation is carried out in accordance with EU label. The EU Ecolabel were for the first time established in 1992, by Regulation no. 880/92 / EEC of 1992. Since then, it has been recognized across Europe and worldwide, and applied to all products at EU level, which a manufacturer from any country wants to place on the market of other Member States under high environmental standards and under eco-label (Janjić, Stojanović-Trivić, 2020).

Traditional hotels and restaurants have become some of the largest consumers of resources (electricity, water) and significant pollutants (waste water, emissions of greenhouse gases). An alternative to these hotels and restaurants are eco-restaurants, the number of which is growing worldwide (Živadinović, 2020). In order to solve the accumulated problems in ecotourism and hotel industry, it is necessary to improve the economic policy and financing of green projects. (Živković, 2020), (Vujović, 2020). Green bonds as sources of green projects financing are relatively new form. However, green bond market has seen an enormous growth in the last years (Stojanović, 2020).

Despite such detailed and strict regulation, most tourists are either not aware of the existence of this sign or do not have enough confidence in it due to insufficient inspections in this area. Therefore, the comparative application of international standards is absolutely desirable. Among the international standards, the ISO organization that created a special group of standards ISO 14000, which specifies the environmental requirements of environmental management, stands out. This series of standards includes 34 standards, among which the most widespread is the ISO 14001: 2015 standard, which is the only standard from this series according to which certification can be performed (Prokić, 2019). The ISO 14001 standard is used to assess the management of the environmental protection system, and can be implemented in any environmental management system (Milošević et al, 2015).

Although, like the national Eco-label of the Republic of Serbia, ISO standards are voluntary, the positive impact they have on attracting environmentally conscious tourists for now has insufficient influence on the owners of catering facilities for their application. Therefore, it is necessary to work on the popularization of these certificates in Serbia and Slovakia in order to be more competitive on the market and attract a growing segment of ecotourists, but also on their strict control. 


\section{CONCLUSION}

According to the results from Group 1 and Group 2, we have proven the great potential of ecotourism in Slovakia. It is a great result for Slovakia to be viewed as an eco-friendly country from the perspective of foreigners, on the other hand, foreigners claimed the lack of marketing and promotion of Slovakia as a touristic destination. Even the local Slovak people have agreed, that marketing strategies to promote domestic ecotourism in different Slovak regions are not effective. It is suggested to engage deeper in the process of marketing to promote the tourism of Slovakia domestically and on the international level. The Slovak government and regional representatives should take more responsibilities to develop Slovak ecotourism potential.

Demand for ecotourism and agrotourism is rising among local people in Slovakia. Regional tourism can boost the local economy, increase job opportunities. Instead of spending money in a foreign destination for a traditional holiday in the resort, it is essential to support the local tourism and local food producers. The aim of ecotourism is to manage recreational activities in an eco-friendly and sustainable manner, with the least possible pollution of the environment. Traditional mass tourism should be transformed into sustainable form of ecotourism, which is the right way of how to protect the nature that can be saved for our next generations.

\section{REFERENCES}

Baláž, D. et al. (2005). Natura 2000- European network of protected areas in the Slovak Republic. National Centre NATURA 2000, State Nature Conservancy of the Slovak Republic.

Carver, E. (2013). Birding in the United States: A demographic and economic analysis addendum to the 2011 national survey of fishing, hunting, and wildlife-associated recreation report. Fish and Wildlife Service, Arlington, Washington.

Council Regulation (EEC) No 880/92 of 23 March 1992 on a Community eco-label award scheme, Official Journal, L 99, 1992, 0001-0007.

Čavlin, M., Škrbić, S., Tepavac, R., Prodanović, R. (2018). Analysis of the Financing Model of Independent Solar Systems of Households in Rural Areas of the Republic of Serbia, Ecologica, 25 (90), 307-314.

European Environment Agency. Wilderness Quality Index (2011), see: https://www.eea.europa.eu/data-and-maps/figures/wilderness-quality-index

Geo Enviroportal. Atlas SR, see: https://geo.enviroportal.sk/atlassr/

Janković, M., Ivannikov, N., Jovanović, L., Gajdobranski, A. (2020). Doprinos zelene ekonomije razvoju ekoturizma i organskoj proizvodnji, Ecologica, 27(98), 217-223.

Janjić, S., Stojanović-Trivić, Eko-označavanje i stanje na tržištu obuće, Tekstilna industrija, br. 1, 2020, 46-56.

Krejić, Ž. R., Milićević, S., Plećić, K., Babić, D. (2019). The Possibility of the Development of Bird Watching as a Specific Form of Tourism in the Deliblato Sands - Case study, Teme: Journal for Social Science, University of Niš, 43(2), 475-488.

Milićević, S., Đorđević, N., Krejić, Ž. (2019). Krupajsko vrelo kao nova eko-turistička destinacija Srbije. Ecologica, 26(96), 481-486.

Milošević, S., Bijelić, I., Adamović, Ž. (2015). Značaj i primena standarda ISO $14001 \mathrm{u}$ upravljanju zaštitom životne sredine, 9. Naučno-stručni skup sa međunarodnim učešćem "QUALITY 2015", Neum, B\&H, pp. 571-580.

Ministerstvo životného prostredia Slovenskej republiky (2019). Zelenšie Slovensko, Stratégia environmentálnej politiky Slovenskej republiky do roku 2030, 1-57. 
Mladenović, M., Bojičić, R. (2020). Razvoj ekoturizma u opštini Štrpce - mogućnosti i perspektive, Ecologica, 27(98), 232-239.

Nikolić, M., Gavrilović, M., Kastratović, E. (2019). Ekonomske i društvene prednosti primene obnovljivih izvora energije - pokretačke snage zelene ekonomije u Srbiji. Ecologica, 27(99), 415-419.

Prokić, D. (2019). Upravljanje zaštitom životne sredine i rizicima sa osvrtom na poljoprivredu, Educons, Fakultet zaštite životne sredine, Sremska Kamenica, pp. 29.

Rojas, F. (2014). The Geothermal potential of Slovakia, see: https://www.thinkgeoenergy.com/the-geothermal-potential-of-slovakia/

Society for Conservation Biology. Conservation Marketing \& Engagement Working Group, see: https://conbio.org/groups/working-groups/conservation-marketing-working-group/

Stojanović, D. (2020). Tržište zelenih obveznica kao inicijativa razvoja koncepta Zelene ekonomije - izazovi i mogućnosti za zemlje u razvoju. Ecologica, 27(97), 58-64.

Škvareninová, L., Kupec, P. (2019). Tourism and recreational potential in Solomon Islands exceeding the benefits of logging, Public recreation and landscape protection- with sense hand in hand, 434-437. ISBN 978-80-7509-659-3.

Štátne lesy TANAPu, see: https://www.lesytanap.sk/

Štetić, S., Trišić, I. (2020). Prirodni resursi za razvoj ekoturizma Specijalnog rezervata prirode „Obedska bara“. Ecologica, 27(98), 224-231.

Švajda, J., Sabo, P. (2013). Manažment chránených území. Vydavatel'stvo Univerzity Mateja Bela - Belianum, B. Bystrica, 5- 128. ISBN 978-80-557-0618-4.

Vujović, S., Premović, J., Arsić, Lj. (2020). Ekološki aspekti materijalne osnove ruralnog turizma, Ecologica, 27(97), 65-69.

Wiezik, M., Niňajová, I., Švajda, J., Elexová, L. (2019). Koncept prírodného turizmu v slovenských podmienkach, Aevis n.o., 3-37.

Živadinović, B. (2020). Eko-restorani u svetu i restorani u Srbiji, Ecologica, 27(97), 70-74.

Živković, D., Petrović, P., Ercegović, M. (2020). Način finansiranja malih i srednjih preduzeća u hotelijerstvu i eko-turizmu. Ecologica, 27(97), 75-81.

United Nations World Tourism Organization - The UNWTO World Tourism Barometer, see: http://mkt.unwto.org/barometer

Održivi turizam: Tema za sve nas! Travel magazine, dostupno na: https://www.travelmagazine.rs/saveti/travel-preporuka/odrzivi-turizam-tema-za-svenas/

Booking.com reveals key findings from its 2019 sustainable travel report, see: https://globalnews.booking.com/bookingcom-reveals-key-findings-from-its-2019sustainable-travel-report

Travel Guard Update, April 2013.

Sačuvajmo čudesne vrste, IUCN Red List, see: https://www.iucn.org/sites/dev/files/import/downloads/iucn_crvena_lista_izlozba.pdf

Biodiverzitet Srbije, IUCN, Red List, see: https://www.iucn.org/sites/dev/files/import/downloads/iucn_crvena_lista_brosura.pdf

EkoKrajina, see: https://ekokrajina.com/ekoturizmus-a-rekreacia/

Službeni glasnik R. Srbije, br. 3/2009.

Službeni glasnik R. Srbije, br. 49/2016. 